\title{
PEMURNIAN ENZIM SEFALOSPORIN-C ASILASE DAN OPTIMASI PROSES KROMATOGRAFI PENUKAR ION
}

\section{Purification of Cephalosporin-C Acylase and Its Optimization of Ion-Exchange Chromatography}

Uli Julia Nasution ${ }^{1 \star}$, Silvia Melinda Wijaya², Ahmad Wibisana ${ }^{1}$, Anna Safarrida1, Indra Rachmawati ${ }^{1}$, Dian Japany Puspitasari ${ }^{1}$, Sidrotun Naim², Anis Herliyanti Mahsunah ${ }^{1}$, Sasmito Wulyoadi ${ }^{1}$, Suyanto ${ }^{1}$

${ }^{1}$ Balai Bioteknologi, BPPT. Gedung 630 Kawasan Puspiptek, Setu, Tangerang Selatan 15314 2Universitas Surya, Grand Serpong Mall Lt. 1 unit F8 \& F9, Jl. M.H. Thamrin Km 2.7, Panunggangan Utara, Pinang, Kota Tangerang, Banten 15143

*Email: uli.julia@bppt.go.id

\begin{abstract}
Cephalosporin- $C$ acylase (CCA) has an important role in the one-step conversion of cephalosporin-C into 7-ACA. Purification process aims to increase specific activity of CCA enzyme. Purification began with cell lysis, ammonium sulphate precipitation, dialysis, ion exchange chromatography (IEC) and size exclusion chromatography. IEC optimization of elution step was also done to compare gradient and isocratic elusion. Purification was capable to increase the enzyme purity upto 33.66 fold, with specific activity of $3.00 \mathrm{U} / \mathrm{mg}$ and the yield reached $41.41 \%$. Optimization of elusion during IEC showed that isocratic protein elusion was more efficient (taking shorter time, 3 column volume $(C V)$ only) than that of gradient batch (up to $9 \mathrm{CV}$ ). SDS-PAGE analysis demonstrated that the recombinant CCA enzyme existed in two types, active enzyme containing $\alpha$-subunit ( $25 \mathrm{kDa}$ ) and $\beta$-subunit (58 $\mathrm{kDa})$, and inactive enzyme (83 $\mathrm{kDa}$ ) as precursor. Furthermore, 30\% ammonium sulphate saturated precipitation was able to precipitate this inactive CCA.
\end{abstract}

Keywords: 7-ACA,CCA, cephalosporin C, protein purification, specific activity

\begin{abstract}
ABSTRAK
Sefalosporin-C asilase (CCA) merupakan enzim yang berperan penting dalam konversi satu tahap sefalosporin-C menjadi 7-ACA. Proses purifikasi merupakan salah satu cara untuk meningkatkan aktivitas spesifik enzim CCA. Proses purifikasi dimulai dari memecah sel, diikuti dengan tahap presipitasi menggunakan amonium sulfat, dialisis, kromatografi penukar ion (IEC) dan kromatografi eksklusi. Optimasi proses IEC pada tahap elusi juga dilakukan untuk membandingkan elusi enzim CCA secara gradien dan isokratik. Proses purifikasi pada penelitian ini mampu meningkatkan kemurnian enzim hingga 33,66 kali, dengan aktivitas spesifik sebesar 3,00 U/mg dan perolehan enzim sebesar 41,41\%. Hasil optimasi IEC pada proses elusi secara isokratik lebih efisien dari segi waktu (hanya membutuhkan 3 kolom volume (CV) dibandingkan dengan secara gradien (sampai $9 \mathrm{CV}$ ). Hasil SDS-PAGE menunjukkan bahwa CCA rekombinan merupakan enzim dengan 2 macam bentuk yaitu enzim aktif, yang terdiri dari subunit $\alpha(25 \mathrm{kDa})$ dan $\beta(58 \mathrm{kDa})$, dan enzim tidak aktif berupa prekursor (83 kDa). Proses presipitasi menggunakan amonium sulfat $30 \%$ tersaturasi dapat mengendapkan prekursor CCA.
\end{abstract}

Kata Kunci: 7-ACA, aktivitas spesifik, CCA, purifikasi protein, sefalosporin C 


\section{PENDAHULUAN}

7-Aminocephalosporanic acid (7-ACA) merupakan senyawa antara yang paling penting untuk membuat antibiotik sefalosporin semi-sintetis dengan spektrum yang luas (Gaurav et al. 2010; Kong et al. 2009), yang dapat dihasilkan dari proses kimiawi atau proses enzimatis. Proses kimiawi memberikan hasil $90 \%$, namun metodenya rumit, tidak ekonomis dan tidak ramah lingkungan dengan penggunaan bahan kimia berbahaya dan pelepasan limbah beracun (Shin et al. 2009; Wang et al. 2012). Maka dari itu, metode kimiawi (Fechtig et al. 1968; Morin et al. 1969) telah digantikan dengan metode enzimatis (Parmar et al. 1998) yang lebih diterima sebagai metode yang ekonomis dan ramah lingkungan (Jobanputra dan Vasait 2015). Proses enzimatis produksi 7-ACA ada 2 macam yaitu proses 2 tahap yang melibatkan 2 macam enzim dan proses 1 tahap yang melibatkan 1 enzim (Pollegioni et al. 2013). Sefalosporin-C asilase (Cephalosporin-C Acylase/CCA) merupakan enzim asilase $\beta$-laktam yang dapat memotong ikatan amida yang berada diantara inti $\beta$-laktam dan rantai samping tanpa merusak cincin siklik $\beta$-laktam dari senyawa sefalosporin $C$ (Cep-C) menjadi senyawa 7-ACA (Gaurav et al. 2010). CCA termasuk dalam protein multimerik dengan subunit heterogen atau heterodimer alphabeta ( $\mathrm{He}$ et al. 2015). Proses biokonversi menggunakan enzim CCA merupakan proses deasilasi dan merupakan proses 1 tahap yang hanya melibatkan satu macam enzim. Namun, aktivitas enzim CCA terhadap substrat Cep-C sangat rendah (Conti et al. 2014) sehingga penelitian untuk meningkatkan aktivitas enzim CCA banyak dilakukan.

Purifikasi atau pemurnian enzim merupakan salah satu cara untuk meningkatkan aktivitas spesifik enzim CCA. Beberapa metode purifikasi yang dapat dilakukan diantaranya adalah presipitasi dengan amonium sulfat dan dialisis. Pada penelitian ini, presipitasi amonium sulfat dilakukan untuk mengendapkan pengotor dan menjaga enzim CCA tetap dalam keadaan terlarut, dengan menambahkan sedikit garam amonium sulfat. Proses ini disebut salting in. Proses presipitasi dengan amonium sulfat sebaiknya diikuti dengan proses dialisis yang dapat menghilangkan sisa garam amonium sulfat dalam sampel (Duong-Ly dan Gabelli 2014).

Kromatografi penukar ion (ion exchange chromatography/IEC) dan kromatografi eksklusi (size exclusion chromatography/SEC) juga merupakan salah satu cara untuk memurnikan enzim. Proses ini memisahkan protein berdasarkan pada muatan ion permukaannya, menggunakan resin yang dimodifikasi dengan gugus kimia bermuatan positif (anion exchanger) atau negatif (cation exchanger) (Tan dan Yiap 2009). Proses ini biasanya cukup efektif pada tahap awal purifikasi (Robinson 2015). Sementara itu, SEC merupakan proses pemisahan protein berdasarkan ukurannya. Proses ini merupakan proses pemisahan yang paling sederhana, karena sampel tidak berikatan dengan media sehingga komposisi buffer tidak mempengaruhi resolusi (Tan dan Yiap 2009). Karena sampel tidak berikatan dengan media dan prosesnya yang tidak memerlukan garam, SEC dapat digunakan untuk menghilangkan sisa garam (Block et al. 2009) dari proses purifikasi sebelumnya dan tidak akan mempengaruhi proses purifikasi selanjutnya. Proses kromatografi afinitas juga dapat dilakukan untuk memurnikan enzim. Namun, proses ini membutuhkan resin yang harganya tergolong lebih mahal dibandingkan resin IEC maupun SEC. Selain itu, proses ini membutuhkan garam berkonsentrasi tinggi yang dapat mengganggu proses purifikasi selanjutnya (Cheung et al. 2012).

Escherichia coli adalah bakteri yang populer digunakan dalam produksi protein rekombinan termasuk enzim rekombinan (Rosano dan Ceccarelli 2014). Saat ini enzim CCA dapat diproduksi menggunakan sistem ekspresi $E$. coli rekombinan yang menghasilkan enzim CCA rekombinan. CCA non-rekombinan memiliki aktivitas yang rendah terhadap substrat Cep-C (bervariasi dari $0-4 \%$ relatif terhadap GL-7-ACA) (Xiao et al. 2014). CCA yang aktif terhadap Cep-C telah ditemukan pada beberapa mikroorganisme dan beberapa gen CCA telah diklon dan disekuens. Namun, CCA tersebut tidak cukup aktif untuk menghidrolis ikatan amida pada posisi ke-7 dari Cep-C, maka tidak cocok untuk proses enzimatis 1 
tahap untuk mendapatkan 7-ACA dari CepC. Beberapa studi genetik telah dilakukan untuk meningkatkan aktivitas CCA terhadap Cep-C (Shin et al. 2009). Sebagai contoh, 2 mutan penghasil CCA dari Pseudomonas N176, M31ßF / H57ßS / H70ßS dan A215 $\alpha \mathrm{Y} / \mathrm{M} 31 \beta \mathrm{F} / \mathrm{H} 70 \beta \mathrm{S}$, masing-masing menunjukkan 3,3 kali dan 4,3 kali peningkatan aktivitas spesifik terhadap CPC, dibandingkan dengan template awalnya (M31ßF), dengan penghapusan inhibisi substrat dan pengurangan inhibisi produk (Xiao et al. 2014). Contoh lainnya adalah mutan penghasil CCA acyll dari Pseudomonas SE83, V122aA / G140aS / F58 $\beta N / 175 \beta T$ / I176 $\beta$ V/S471 $\beta C$ (disebut juga S12) yang menunjukkan peningkatan aktivitas spesifik sebesar 7,5 kali lipat jika dibandingkan dengan wild-type (Xiao et al. 2014; Shin et al. 2009).

Salah satu cara untuk meningkatkan aktivitas spesifik enzim CCA rekombinan adalah dengan memurnikan enzim dan melibatkan beberapa tahap purifikasi. Tujuan penelitian ini adalah untuk melakukan purifikasi enzim CCA yang dihasilkan oleh $E$. coli BL21(DE3)/S12 dan melakukan optimasi pada tahap kromatografi penukar ion.

\section{BAHAN DAN METODE}

\section{Bahan kimia}

Bahan-bahan yang digunakan pada penelitian ini adalah Luria Broth (LB) cair dan agar media (Tripton $1 \%$ (Oxoid ${ }^{\mathrm{TM}}$ ), $\mathrm{NaCl}$ $1 \%$ (Merck), yeast extract $0,5 \%$ (Oxoid $^{\mathrm{TM}}$ ), agar 2\% (Oxoid ${ }^{\mathrm{TM}}$ ); $\mathrm{NaOH} 1 \mathrm{~N}$ (Merck); Isopropyl $\quad \beta$-D-1-thiogalactopyranoside (IPTG) (Thermo Scientific ${ }^{\mathrm{TM}}$ ), ampisilin (MP Biomedicals); phenylmethane sulfonyl fluoride (PMSF) (MP Biomedicals); Tris (Bio Basic Canada); $\mathrm{HCl}$ (Merck); amonium sulfat (Merck); $\mathrm{NaCl}$ (Merck); Etanol 96\%; Coomasie brilliant blue R250 (Merck), metanol (Merck), asam asetat (Merck); mercaptoethanol (Bio Basic Canada); gliserol (Merck), bromophenol blue (ACS); Cephalosporin-C (Biorbyt); 7-Amino Cephalosporanic Acid (Tokyo Chemical Industry Ltd.); paraDimethylaminobenzaldehyde (PDMAB); Pierce $^{\mathrm{TM}}$ Coomasie Plus (Bradford) Assay Kit (Thermo Scientific ${ }^{\mathrm{TM}}$ ); Diethylaminoethanol Sepharose Fast Flow (DEAE Sepharose FF).

\section{Preparasi media pertumbuhan bakteri}

Untuk regenerasi dan pemeliharaan mikroba, bakteri penghasil CCA ditumbuhkan dalam media LB agar dengan komposisi (g/L): $10 \mathrm{~g}$ Tripton, $10 \mathrm{~g} \mathrm{NaCl}, 5 \mathrm{~g}$ yeast extract dan $20 \mathrm{~g}$ agar. Kemasaman $\mathrm{pH}$ diatur menjadi 7,5 dengan $\mathrm{NaOH} 1 \mathrm{~N}$. Media disterilisasi pada suhu $121^{\circ} \mathrm{C}$ selama 20 menit. Sebanyak $100 \mu \mathrm{g} / \mathrm{mL}$ larutan Ampisilin dengan konsentrasi $100 \mathrm{mg} / \mathrm{mL}$ ditambahkan ke dalam media setelah suhu turun menjadi $\pm 55^{\circ} \mathrm{C}$. Sebagai media untuk pembuatan inokulum digunakan media LB cair dengan komposisi yang sama seperti media regenerasi/pemeliharaan tanpa penambahan agar.

\section{Bakteri dan fermentasi CCA}

Bakteri E. coli BL21(DE3), hasil transformasi dengan gen $\mathrm{S} 12$ dalam plasmid pET21a, digunakan untuk memproduksi enzim CCA rekombinan. Gen $\mathrm{S} 12$ merupakan hasil modifikasi gen Acy // dari Pseudomonas SE83. Produksi CCA dilakukan mengacu pada metode Martius et al. (2018) dengan sedikit modifikasi. Koloni tunggal dari $E$. coli yang telah diregenerasi selama 18 jam ditumbuhkan pada $5 \mathrm{~mL}$ media LB yang mengandung ampisilin 100 $\mu \mathrm{g} / \mathrm{mL}$ dan dikultivasi dalam orbital shaker dengan kecepatan $200 \mathrm{rpm}$ dan suhu $37^{\circ} \mathrm{C}$. Setelah itu, kultur overnight sebanyak $1 \%$ diinokulasikan pada $50 \mathrm{~mL}$ media LB dan diinkubasi selama 2 jam, suhu $37^{\circ} \mathrm{C}$ dan kecepatan 200 rpm, menggunakan New Brunswick $^{\mathrm{TM}}$ Innova $^{\circledR} 44$ incubator orbital shaker. Induksi IPTG sebanyak 0,8 mM dilakukan jika nilai absorbansi sel $\mathrm{OD} \lambda_{600}$ telah mencapai 0,4-0,8. Inkubasi kembali dilakukan selama 24 jam pada suhu $37^{\circ} \mathrm{C}$ dengan kecepatan 150 rpm.

\section{Purifikasi enzim: presipitasi dan dialisis}

Sel dari $50 \mathrm{~mL}$ media fermentasi dipanen dan dipisahkan antara supernatan dan sel dengan cara mensentrifugasi kultur fermentasi menggunakan sentrifuse pada kecepatan 12.000 rpm selama 5 menit. Pelet sel yang telah dipisahkan dari supernatannya dicuci dengan buffer Tris- $\mathrm{HCl}$ $20 \mathrm{mM}, \mathrm{pH} 8,0$ sebanyak 1 kali. Pelet diresuspensi dengan $5 \mathrm{~mL}$ Tris- $\mathrm{HCl} 20 \mathrm{mM}$, $\mathrm{pH}$ 8,0 dan ditambahkan PMSF sebanyak 1 $\mathrm{mM}$. Sel dipecah (lysis) menggunakan alat Branson Ultrasonic Sonifier ${ }^{T M}$ S-450 dengan 
kondisi pulse ON 5 detik, pulse OFF 20 detik, amplitudo 25\%, pulse temperature $10^{\circ} \mathrm{C}$, suhu maksimum $20^{\circ} \mathrm{C}$, selama 5 menit. Suspensi hasil lisis disentrifugasi pada suhu $4^{\circ} \mathrm{C}$, kecepatan $12.000 \mathrm{rpm}$, selama 20 menit. Supernatan dipisahkan dari pelet pecahan sel. Pelet diresuspensi dengan buffer Tris- $\mathrm{HCl} 20 \mathrm{mM}, \mathrm{pH} 8,0$ menjadi $5 \mathrm{~mL}$ dan disimpan dalam pendingin suhu $-20^{\circ} \mathrm{C}$ untuk pengecekan enzim CCA yang masih menempel di pecahan sel.

Supernatan hasil lisis dipresipitasi menggunakan amonium sulfat dengan konsentrasi akhir $30 \%$ tersaturasi. Pengadukan larutan dilakukan dalam ruang dingin selama 45 menit menggunakan alat Stuart $^{\circledR}$ Stirrer Hotplate CB162 dan kemudian disentrifugasi pada suhu $4^{\circ} \mathrm{C}$ kecepatan $12.000 \mathrm{rpm}$ selama 15 menit. Supernatan dipisahkan dari peletnya. Pelet diresuspensi dengan buffer Tris- $\mathrm{HCl} 20$ mM, pH 8,0 menjadi $5 \mathrm{~mL}$ dan disimpan dalam suhu $-20^{\circ} \mathrm{C}$.

Supernatan hasil presipitasi didialisis menggunakan filter Amicon ${ }^{\circledR}$ Ultra-15 Centrifugal Filter Units Molecular Weight Cut_off (MWCO) $50.000 \mathrm{Da}$ dengan melakukan sentrifugasi pada suhu $4^{\circ} \mathrm{C}$, kecepatan 5.000 rpm selama 5 menit.

\section{Pemurnian via kromatografi penukar ion}

Sebanyak $10 \mathrm{~mL}$ larutan hasil dialisis dicampur dengan resin DEAE Sepharose FF yang telah diekuilibrasi dengan buffer Tris$\mathrm{HCl} 20 \mathrm{mM}$, pH 8,0 dalam tabung Falcon dan diinkubasi dalam shaker (Stuart ${ }^{\circledR}$ Mini Orbital Shaker SSM-1) dengan kecepatan 100 rpm selama satu malam (16 jam). Campuran resin dan sampel yang telah diinkubasi dimasukkan ke dalam kolom dan dibiarkan \pm 30 menit. Selanjutnya dilakukan pencucian resin dengan Tris- $\mathrm{HCl} 20 \mathrm{mM}, \mathrm{pH}$ 8,0 yang mengandung $50 \mathrm{mM} \mathrm{NaCl}$ sebanyak $5 \mathrm{CV}$ (column volume).

Setelah dilakukan pencucian resin, enzim CCA yang terikat pada resin dielusi menggunakan dua metode, yaitu metode elusi secara bertahap (batch step wise) dan cara isokratik. Elusi secara bertahap dilakukan dengan menggunakan eluen buffer Tris- $\mathrm{HCl} 20 \mathrm{mM}$, pH 8,0 yang mengandung $\mathrm{NaCl}$ dengan konsentrasi 100 , 150, 200 dan 300 mM. Setiap elusi dilakukan menggunakan volume eluen sebanyak $3 \mathrm{CV}$. Elusi secara isokratik dilakukan menggunakan buffer Tris- $\mathrm{HCl} 20 \mathrm{mM}, \mathrm{pH} \quad 8,0$ dan mengandung $\mathrm{NaCl} 200 \mathrm{mM}$ sebanyak $3 \mathrm{CV}$. Fraksi hasil elusi ditampung setiap 3 hingga $4 \mathrm{~mL}$. Fraksi yang mengandung enzim CCA digabung untuk proses pemurnian selanjutnya. Pencucian resin selanjutnya dilakukan menggunakan $\mathrm{NaCl} 2 \mathrm{M}$ sebanyak $5 \mathrm{CV}$ untuk menghilangkan sisa protein yang masih terikat sehingga resin dapat digunakan untuk proses pemurnian berikutnya.

\section{Pemurnian via kromatografi eksklusi}

Sampel hasil IEC dimasukkan ke dalam kolom berisi Sephadex G-50 yang telah diekuilibrasi. Elusi dilakukan dengan Tris- $\mathrm{HCl} 20 \mathrm{mM}$, pH 8,0 sebanyak $1 \mathrm{CV}$ dan fraksi ditampung setiap $4 \mathrm{~mL}$.

\section{Analisis aktivitas enzim}

Aktivitas enzim CCA ditentukan dengan mengukur jumlah senyawa 7-ACA yang terbentuk sebagai hasil hidrolisis senyawa Cep-C oleh enzim CCA. Larutan enzim dan substrat Cep-C yang digunakan, masingmasing diinkubasi terlebih dahulu ke dalam waterbath sehingga suhunya mencapai $37^{\circ} \mathrm{C}$. Sebanyak $25 \mu \mathrm{L}$ larutan substrat Cep-C $2 \%$ dimasukkan ke dalam mikrotube dan ditambahkan dengan $25 \mu \mathrm{L}$ larutan enzim sehingga terjadi reaksi hidrolisis. Reaksi hidrolisis dilakukan selama 10 menit dan suhu dipertahankan pada $37^{\circ} \mathrm{C}$. Selanjutnya, sampel diinkubasi dalam waterbath sehingga suhunya $37^{\circ} \mathrm{C}$ selama 10 menit. Reaksi hidrolisis dihentikan dengan menambahkan $300 \mu \mathrm{L}$ larutan stop reaksi. Larutan hasil hidrolisis yang telah dihentikan reaksinya selanjutnya ditambah dengan $50 \mu \mathrm{L}$ PDMAB 0,5\% untuk pewarnaan dan diinkubasi selama 10 menit pada suhu kamar. Selanjutnya larutan disentrifugasi pada suhu $4^{\circ} \mathrm{C}$, pada kecepatan $10.000 \mathrm{rpm}$ selama 3 menit. Sebanyak $100 \mu \mathrm{L}$ supernatan diambil dan dimasukkan ke dalam microplate 96-sumur, dan selanjutnya diukur absorbansinya pada panjang gelombang $415 \mathrm{~nm}$ menggunakan Microplate Reader. Satu unit aktifitas enzim didefinisikan sebagai jumlah enzim yang diperlukan untuk menghasilkan 7-ACA sebanyak $1 \mu \mathrm{mol}$ pada suhu $37^{\circ} \mathrm{C}$ per menit.

\section{Analisis protein via Bradford Assay}

Konsentrasi protein dalam sampel diukur menggunakan metode Bradford Assay, sesuai dengan prosedur dari Thermo Scientific $^{\mathrm{TM}}$. Sampel disiapkan dengan 

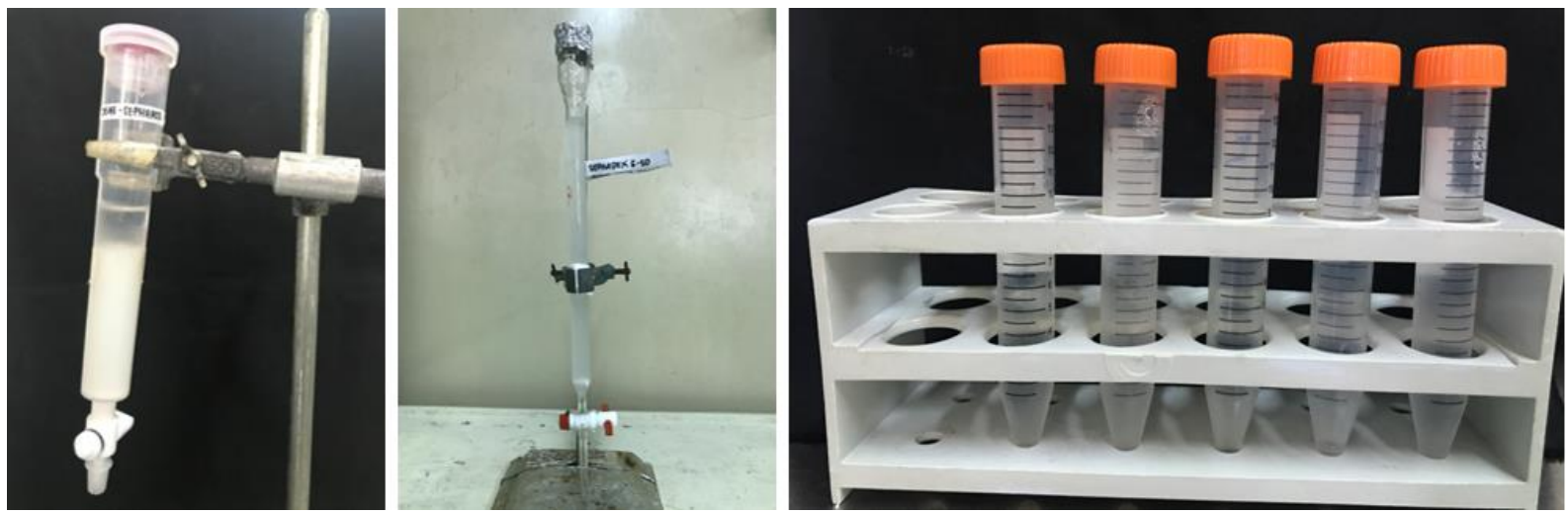

Gambar 1. Kolom Sephadex G-50 (kiri), kolom DEAE Sepharose FF (tengah), hasil elusi IEC fraksi 2-6 (kanan)

menambahkan $45 \mu \mathrm{L}$ sampel ke dalam $2.250 \mu \mathrm{L}$ Coomasie Protein Assay Reagent dan selanjutnya diinkubasi selama 10 menit pada suhu kamar. Absorbansi sampel selanjutnya diukur pada panjang gelombang $595 \mathrm{~nm}$. Sebagai blanko digunakan buffer Tris- $\mathrm{HCl} 20 \mathrm{mM} \mathrm{pH} \mathrm{8,0} \mathrm{untuk} \mathrm{menggantikan}$ sampel dan sebagai larutan standar digunakan Protein Bovine Serum Albumin (BSA).

\section{Analisis SDS-PAGE}

Elektroforesis gel poliakrilamida (SDSPAGE) dilakukan menurut Laemmli (1970) menggunakan protokol Bio-Rad Protean II gel apparatus. Gel SDS PAGE 10\% digunakan untuk menganalisa protein hasil pemurnian. Sampel dilarutkan dalam $6 \times$ loading sample buffer (Tris-HCl 0,5 M (pH 6,8) 75\%, gliserol $63 \%$, SDS 9\%, dan bromophenol blue 0,03\% dalam DW). $\beta$-mercaptoethanol ditambahkan sebanyak $3 \%$ ke dalam setiap sampel. Elektroforesis dilakukan menggunakan running buffer (Tris 0,3\%, glisin 0,14\%, dan SDS $0,1 \%$ dalam DW) dengan alat ATTO AE6500 Dual Mini Slab, pada 30-40 mA selama 1,5 jam. Pewarnaan gel untuk visualisasi pita protein pada gel dilakukan menggunakan Coomasie blue R250 staining solution.

\section{HASIL DAN PEMBAHASAN}

\section{Purifikasi Sefalosporin-C Asilase}

Purifikasi enzim adalah proses yang bertujuan untuk meningkatkan kemurnian enzim yang dinyatakan sebagai aktivitas spesifik enzim. Kemurnian enzim ini penting karena adanya beberapa senyawa kontaminan yang dapat mempengaruhi kerja enzim, misalnya menghambat aktivitas enzim (inhibitor) atau memiliki kemampuan yang mirip dengan enzim target namun menghasilkan produk yang berbeda atau tidak diinginkan.

Purifikasi CCA diawali dengan memecah sel (cell lysis) dalam buffer Tris$\mathrm{HCl} 20 \mathrm{mM}$ menggunakan alat sonikator karena enzim ini berupa enzim intraselular. Pemecahan sel ditujukan untuk melepaskan protein dari sel inang menjadi bentuk terlarut (Tan dan Yiap 2009; Ma et al. 2014). PMSF $1 \mathrm{mM}$ ditambahkan untuk mencegah degradasi enzim target oleh enzim protease. Pecahan sel dan pengotor dipisahkan dengan sentrifugasi $10.000 \mathrm{rpm}$ selama 10 menit. Sebagai tahap awal pemurnian, presipitasi dilakukan dengan menambahkan amonium sulfat dengan konsentrasi $30 \%$ kejenuhan yang dilakukan pada suhu $10^{\circ} \mathrm{C}$. Presipitasi dengan amonium sulfat ditujukan untuk mengendapkan zat-zat pengotor dan protein-protein kecil (Tan dan Yiap 2009; Ma et al. 2014). Larutan hasil presipitasi dipisahkan dari endapan protein dan selanjutnya didialisis untuk menghilangkan garam amonium sulfat yang tersisa pada sampel (Duong-Ly dan Gabelli 2014). Kemurnian enzim yang diperoleh meningkat 1,20 kali dengan perolehan nilai sebesar $65,97 \%$ (Tabel 1).

\section{Pemurnian via kromatografi penukar ion Pemisahan enzim dengan kromatografi penukar ion (IEC)} menggunakan resin DEAE Sepharose FF (anion exchanger) dilak ukan berdasarkan muatan ionik permukaannya (Gambar 1). Pada $\mathrm{pH}$ di atas nilai pl (point of isoelectric), maka protein akan bermuatan negatif sehingga protein akan berikatan dengan resin yang bermuatan positif (anion exchanger). Sebaliknya, pada $\mathrm{pH}$ di bawah 
nilai pl, protein akan mengikat senyawasenyawa dalam medium yang bermuatan negatif (cation exchanger). Protein yang berikatan lemah dengan resin akan terelusi dengan buffer yang mengandung garam berkonsentrasi rendah, sedangkan protein yang berikatan kuat dengan resin akan membutuhkan konsentrasi garam yang lebih tinggi untuk elusinya (Tan dan Yiap 2009; Tripathi 2016). Pada penelitian ini, pada proses elusi enzim CCA secara isokratik menggunakan buffer Tris- $\mathrm{HCl} 20 \mathrm{mM}, \mathrm{pH} 8$ yang mengandung $\mathrm{NaCl}$ sebesar $200 \mathrm{mM}$ menunjukkan hasil yang lebih baik jika dibandingkan dengan elusi dengan metode gradien secara bertahap. Pada elusi isokratik kemurnian enzim secara keseluruhan (overall fold) meningkat 14,11 kali dengan perolehan keseluruhan (overall yield) sebesar 23,87\% (Tabel 1). Sementara itu pada elusi stepwise kemurnian enzim secara proses individual meningkat sebesar 11,45 kali dengan perolehan individual sebesar $36,51 \%$ (Tabel 2). Secara individual, proses pemurnian enzim menggunakan kromatografi penukar ion menghasilkan peningkatan kemurnian sebesar 11,41 kali dan perolehan sebesar $36,51 \%$ (Tabel 1).

\section{Pemurnian via kromatografi eksklusi}

Proses purifikasi dilanjutkan dengan proses kromatografi eksklusi (SEC) dengan kolom berisi resin Sephadex G-50 (Gambar 1), yang memisahkan protein berdasarkan ukuran molekulnya. Protein yang berukuran lebih kecil akan terperangkap dalam pori-pori resin sehingga terelusi lebih lambat, sedangkan protein besar akan terelusi lebih cepat (Tan dan Yiap 2009; Tripathi 2016). Pada penelitian ini, pemurnian enzim CCA

Tabel 1. Data analisis sampel tiap tahapan purifikasi CCA yang dihasilkan oleh E. coli BL21(DE3)/S12

\begin{tabular}{lccccccc}
\hline $\begin{array}{l}\text { Tahapan } \\
\text { purifikasi }\end{array}$ & $\begin{array}{c}\text { Aktivitas } \\
\text { enzim } \\
(\mathrm{U} / \mathrm{mL})\end{array}$ & $\begin{array}{c}\text { Konsentrasi } \\
\text { protein } \\
(\mathrm{mg} / \mathrm{mL})\end{array}$ & $\begin{array}{c}\text { Aktivitas } \\
\text { spesifik } \\
(\mathrm{U} / \mathrm{mg})\end{array}$ & $\begin{array}{c}\text { Perolehan } \\
\text { enzim }(\%)\end{array}$ & $\begin{array}{c}\text { Perolehan enzim } \\
\text { secara } \\
\text { individual }[\%]\end{array}$ & $\begin{array}{c}\text { Peningkatan } \\
\text { kemurnian/ } \\
\text { fold }(\mathrm{x})\end{array}$ & $\begin{array}{c}\text { Peningkatan } \\
\text { kemurnian/fold } \\
\text { (secara proses } \\
\text { individual) }(\mathrm{x})\end{array}$ \\
\hline $\begin{array}{l}\text { Supernatan } \\
\text { hasil lisis }\end{array}$ & 1,91 & 21,46 & 0,09 & 100,00 & 100,00 & 1,00 & 1,00 \\
\hline $\begin{array}{l}\text { Supernatan } \\
\text { presipitasi } \\
\text { setelah didialisis }\end{array}$ & 1,26 & 11,77 & 0,11 & 65,97 & 65,97 & 1,20 & 1,20 \\
$\begin{array}{l}\text { DEAE Sepharose } \\
\text { FF (IEC) }\end{array}$ & 0,46 & 0,36 & 1,26 & 23,87 & 36,51 & 14,11 & 11,45 \\
$\begin{array}{l}\text { Sephadex G-50 } \\
\text { (SEC) }\end{array}$ & 0,79 & 0,26 & 3,00 & 41,41 & 171,74 & 33,66 & 2,38 \\
\hline
\end{tabular}

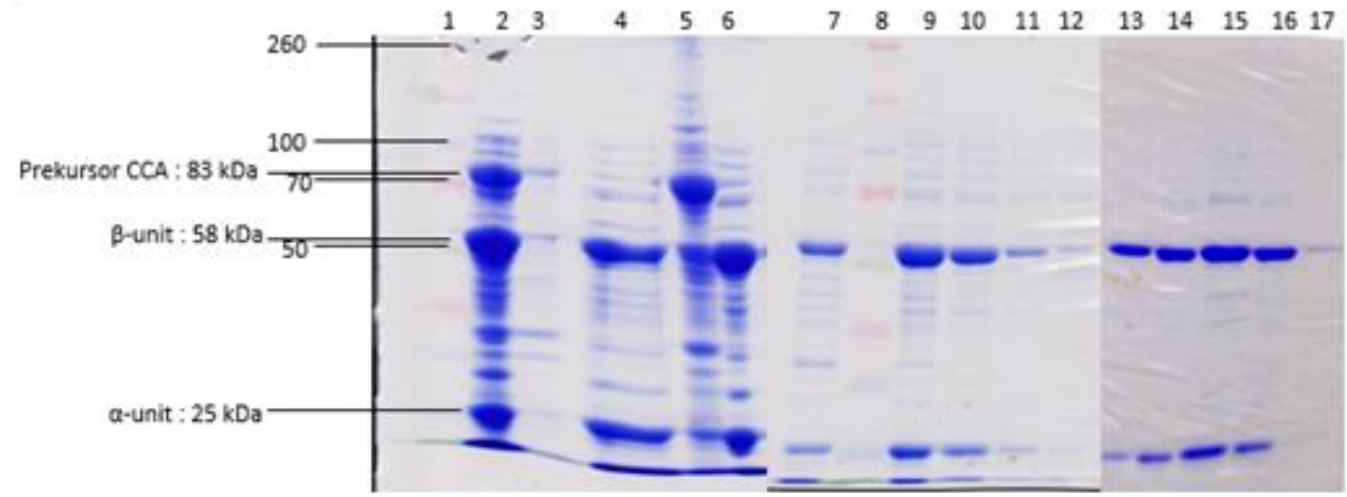

\section{Keterangan:}

1. Marka protein

2. Supernatan hasil lisis

3. Pelet hasil lisis

4. Supernatan hasil presipitasi

5. Pelet hasil presipitasi

6. Hasil dialisis

7. Elusi IEC fraksi 2 (Tris- $\mathrm{HCl} 20 \mathrm{mM} \mathrm{pH} 8+200 \mathrm{mM} \mathrm{NaCl}$ )

8. Marka protein
9. Elusi IEC fraksi $3($ Tris $-\mathrm{HCl} 20 \mathrm{mM} \mathrm{pH} 8+200 \mathrm{mM} \mathrm{NaCl})$

10. Elusi IEC fraksi 4 (Tris- $\mathrm{HCl} 20 \mathrm{mM} \mathrm{pH} 8+200 \mathrm{mM} \mathrm{NaCl}$ )

11. Elusi IEC fraksi 5 (Tris- $\mathrm{HCl} 20 \mathrm{mM} \mathrm{pH} 8+200 \mathrm{mM} \mathrm{NaCl}$ )

12. Elusi IEC fraksi 6 (Tris- $\mathrm{HCl} 20 \mathrm{mM} \mathrm{pH} 8+200 \mathrm{mM} \mathrm{NaCl}$ )

13. Elusi SEC fraksi 5

14. Elusi SEC fraksi 6

15. Elusi SEC fraksi 7

16. Elusi SEC fraksi 8

17. Elusi SEC fraksi 9

Gambar 2. Analisis hasil purifikasi batch 1 dengan metode SDS PAGE 
Tabel 2. Perbandingan purifikasi CCA dengan metode IEC yang dielusi isokratik dan gradient secara bertahap

\begin{tabular}{|c|c|c|c|c|c|c|c|c|c|c|}
\hline \multirow{2}{*}{$\begin{array}{l}\text { Tahapan } \\
\text { purifikasi }\end{array}$} & \multicolumn{2}{|c|}{$\begin{array}{c}\text { Aktivitas } \\
\text { enzim }(U / \mathrm{mL})\end{array}$} & \multicolumn{2}{|c|}{$\begin{array}{c}\text { Konsentrasi } \\
\text { protein }(\mathrm{mg} / \mathrm{mL})\end{array}$} & \multicolumn{2}{|c|}{$\begin{array}{c}\text { Aktivitas } \\
\text { spesifik }(\mathrm{U} / \mathrm{mg})\end{array}$} & \multicolumn{2}{|c|}{$\begin{array}{l}\text { Perolehan } \\
\text { enzim (\%) }\end{array}$} & \multicolumn{2}{|c|}{$\begin{array}{c}\text { Peningkatan } \\
\text { kemurnian/fold }(x)\end{array}$} \\
\hline & $\mathrm{A}$ & $\mathrm{B}$ & $\mathrm{A}$ & $\mathrm{B}$ & $\mathrm{A}$ & $\mathrm{B}$ & $\mathrm{A}$ & $\mathrm{B}$ & $\mathrm{A}$ & $\mathrm{B}$ \\
\hline $\begin{array}{l}\text { Supernatan } \\
\text { lisis }\end{array}$ & 1,91 & 0,76 & 21,46 & 4,51 & - & 0,17 & 100,00 & 100,00 & - & 1,00 \\
\hline $\begin{array}{l}\text { Supernatan } \\
\text { presipitasi } \\
\text { dialisis }\end{array}$ & 1,26 & 0,80 & 11,77 & 2,81 & - & 0,28 & 65,97 & 104,98 & - & 1,69 \\
\hline \multicolumn{11}{|l|}{ Elusi IEC: } \\
\hline $100 \mathrm{mM}$ & - & 0,08 & - & 0,03 & - & 2,49 & - & 9,94 & - & 14,77 \\
\hline $150 \mathrm{mM}$ & - & 0,10 & - & 0,07 & - & 1,39 & - & 13,43 & - & 8,25 \\
\hline $200 \mathrm{mM}$ & 0,46 & 0,14 & - & 0,12 & 1,26 & 1,18 & 23,87 & 18,04 & 14,11 & 6,98 \\
\hline $300 \mathrm{mM}$ & - & 0,09 & - & 0,06 & - & 1,50 & - & 11,68 & - & 8,87 \\
\hline
\end{tabular}

Keterangan: $\mathrm{A}$ = isokratik; $\mathrm{B}$ = bertahap

menggunakan kromatografi eksklusi dapat meningkatkan kemurnian enzim secara keseluruhan sebesar 33,66 kali dengan perolehan secara keseluruhan sebesar $41,41 \%$. Secara individual, proses pemurnian enzim menggunakan kromatografi eksklusi menghasilkan peningkatan kemurnian sebesar 2,38 kali dan perolehan sebesar 171,74\% (Tabel 1). Aktifitas spesifik enzim murni pada akhir proses pemurnian yang diperoleh mencapai $3,00 \mathrm{U} / \mathrm{mg}$.

\section{Karakterisasi awal enzim CCA}

Konfirmasi hasil pemurnian enzim CCA dilakukan dengan melihat pita protein menggunakan gel SDS PAGE seperti ditunjukkan pada Gambar 2. Pada proses fermentasi dihasilkan enzim CCA dengan 2 macam bentuk yaitu enzim aktif dan enzim tidak aktif yang berupa prekursor. Kedua enzim ini mempunyai ukuran yang mirip sekitar $83 \mathrm{kDa}$. Pada proses pemurnian menggunakan amonium sulfat $30 \%$ tersaturasi, prekursor enzim CCA dapat dipisahkan (Gambar 2, lajur 4 dan 5). Prekursor enzim CCA merupakan enzim tidak aktif yang berbentuk dimer terdiri dari 2 subunit, yaitu subunit $\alpha$ dan $\beta$, dan masih memiliki peptida antara (spacer peptide) yang terdiri dari 9 asam amino dan tidak tereduksi dengan teknik SDS-PAGE terdenaturasi. Enzim CCA aktif merupakan enzim yang sudah tidak memiliki spacer peptide, dan terdenaturasi menjadi subunit $\alpha$ dan $\beta$ dengan ukuran, berturut-turut, sekitar 25 dan $58 \mathrm{kDa}$ pada saat analisa dengan SDS-PAGE. Pemurnian selanjutnya menggunakan kromatografi penukar ion dan eksklusi juga menunjukkan peningkatan kemurnian enzim CCA yang ditunjukkan dengan hilangnya pita protein pengotor.

\section{KESIMPULAN}

CCA Pada penelitian ini pemurnian enzim pengendapan dengan amonium sulfat, kromatogragi penukar ion dan kromatografi eksklusi. Dengan metode pengendapan amonium sulfat diperoleh peningkatan kemurnian sebesar 1,2 kali dengan perolehan sebesar 65,97\%. Pemurnian enzim dengan metode kromatografi penukar ion diperoleh peningkatan kemurnian sebesar 14,11 kali dengan perolehan sebesar $23,87 \%$. Tahap pemurnian terakhir dilakukan dengan menggunakan kromatografi eksklusi dan diperoleh peningkatan kemurnian enzim sebesar 33,66 kali dengan perolehan sebesar $41,41 \%$. Aktifitas spesifik enzim CCA hasil pemurnian adalah $3,00 \mathrm{U} / \mathrm{mL}$.

\section{DAFTAR PUSTAKA}

Block $H$, Maertens B, Spriestersbach A, Brinker N, Kubicek J, Fabis R, Labahn J, Schafer F (2009) Immobilized-metal affinity chromatography (IMAC): A review. Methods Enzymol 463:439473. doi:10.1016/S0076-6879(09)63027-5

Cheung RC, Wong JH, Ng TB (2012) Immobilized metal ion affinity chromatography: A review on its applications. Appl Microbiol Biotechnol 
96:1411-1420. doi: 10.1007/s00253012-4507-0

Conti G, Pollegioni L, Molla G, Rosini E (2014) Strategic manipulation of an industrial biocatalyst - Evolution of a cephalosporin $\mathrm{C}$ acylase. FEBS J 281:2443-2455. doi: 10.1111/febs.12798

Duong-Ly KC, Gabelli SB (2014) Salting out of proteins using ammonium sulfate precipitation. Methods Enzymol 541:85-94. doi: 10.1016/B978-0-12420119-4.00007-0

Fechtig B, Peter $\mathrm{H}$, Bickel $\mathrm{H}$, Wischer $\mathrm{E}$ (1968) Concerning the preparation of 7-amino-cephalosporanic acid. Helv Chim Acta 51:1108-1119. doi: 10.1002/hlca.19680510513

Gaurav K, Kundu K, Kundu S (2010) Biosynthesis of Cephalosporin-C Acylase Enzyme: Optimal Media Design, Purification, and Characterization. Artif Cells Blood Substit Immobil Biotechnol 38:277-283. doi: 10.3109/10731199.2010.482036

He H, Luo H, Li X, Wang X, Liang C, Wei $Y Y$, Shen $Z$ (2015) Immobilization and stabilization of cephalosporin C acylase on aminated support by crosslinking with glutaraldehyde and further modifying with aminated macromolecules. Biotechnol Prog 31:387-395. doi: 10.1002/btpr.2044

Jobanputra AH, Vasait R (2015) Cephalosporin C acylase from Pseudomonas species: Production and enhancement of its activity by optimization of process parameters. Biocatal Agric Biotechnol 4:465-470. doi: 10.1016/j.bcab.2015.06.009

Kong K-F, Schneper L, Mathee K (2009) Beta-lactam antibiotics: from antibiosis to resistance and bacteriology. APMIS 118:1-36. doi: 10.1111/j.16000463.2009.02563.x

Laemmli UK (1970) Cleavage of structural proteins during the assembly of the head of bacteriophage T4. Nature 227:680-685. doi: 10.1038/227680a0

Ma X, Su E, Deng S, Xie Y, Wei D (2014) An efficient method for recovering recombinant Cephalosporin C deacetylase from the cytoplasm of $E$. coli cells. Chemical and Biochemical Engineering Quarterly 28:349-355. doi: 10.15255/CABEQ.2013.1904
Martius E, Wibisana A, Ardiyani Y (2018) The optimization of soluble cephalosporin $C$ acylase expression in E. coli. IJES 7:29-34. doi:10.9790/1813-0703012934

Morin R, Jackson B, Flynn E, Roseske R, Andrews $S$ (1969) Chemistry of cephalosporin antibiotics XIV: reaction of cephalosporin $\mathrm{C}$ with nitrosyl chloride. J Am Chem Soc 91:13961400. doi: 10.1021/ja01034a022

Parmar A, Kumar H, Marwaha S, Kenedy J (1998) Recent trends in enzymatic conversion of Cephalosporin C to 7Aminocephalosporanic Acid (7-ACA). Crit Rev Biotechnol 18:1-12. doi: 10.1080/0738-859891224194

Pollegioni L, Rosini E, Molla G (2013) Cephalosporin C acylase: dream and//or) reality. Appl Microbiol Biotechnol 97:2341-2355. doi: 10.1007/s00253-013-4741-0

Robinson PK (2015) Enzymes: principle and biotechnological applications. Essays Biochem 59:1-41. doi:10.1042/bse0590001

Rosano G, Ceccarelli E (2014) Recombinant protein expression in Escherichia coli: advances and challenges. Front Microbiol 5:172. doi: 10.3389/fmicb.2014.00172

Shin YC, Jeon J, Jung KH, Park MR, Kim Y. (2009) Cephalosporin C acylase mutant and method for preparing 7ACA using same. United States of America Paten No. US 7,592,168 B2.

Tan SC, Yiap BC (2009) DNA, RNA, and protein extraction: The past and the present. J Biomed Biotechnol. 2009:110. doi: $10.1155 / 2009 / 574398$

Tripathi N (2016) Production and purification of recombinant proteins from Escherichia coli. ChemBioEng Reviews 3:116-133. doi: 10.1002/cben.201600002

Wang Y, Yu H, Song W, An M, Zhang J, Luo $H$, Shen $Z$ (2012) Overexpression of synthesized cephalosporin C acylase containing mutations in the substrate transport tunnel. J Biosci Bioeng 113:3641. doi: 10.1016/j.jbiosc.2011.08.027

Xiao Y, Huo X, Qian Y, Zhang Y, Chen G, Ouyang $P$, Lin $Z$ (2014) Engineering of a CPC acylase using a facile $\mathrm{pH}$ indicator assay. $\mathrm{J}$ Ind Microbiol Biotechnol 41:1617-1625. doi: 10.1007/s10295-014-1501-9 